\title{
Social and economic factors influencing the age of menarche of female students at the Faculty of Medicine and Health Sciences at the Jan Kochanowski University in Kielce compared to developmental norms
}

\author{
Wpływ czynników społeczno-ekonomicznych na wiek menarche studentek \\ Wydziału Lekarskiego i Nauk o Zdrowiu Uniwersytetu Jana Kochanowskiego \\ w Kielcach w porównaniu z normami rozwojowymi
}

\author{
Tadeusz Kuder ${ }^{1}$, Edyta Suliga¹, Ewa Mańka², Olga Frieman² \\ 'Department of Anatomy, Institute of Medical Sciences, Faculty of Medicine and Health Sciences, Jan Kochanowski \\ University, Kielce, Poland \\ Head of the Department: Prof. Tadeusz Kuder MD, PhD \\ ${ }^{2}$ student, Institute of Medical Sciences, Faculty of Medicine and Health Sciences, Jan Kochanowski University, Kielce, Poland \\ Head of the Faculty: Prof. Marianna Janion PhD
}

Key words: menarche age, puberty, socio-economic conditions.

Słowa kluczowe: wiek menarche, dojrzewanie płciowe, warunki społeczno-ekonomiczne.

\begin{abstract}
Introduction: The age of menarche is the beginning of the final puberty phase. It is used as an assessment criterion for girls' sexual maturation. Despite much research in the area, the issue is still valid because, along with improvement of the quality of life and socio-economic conditions, a tendency has been observed for girls go through puberty earlier.

Aim of the research: To analyse the menarche age of female students at the Faculty of Medicine and Health Sciences Jan Kochanowski University (JKU) in Kielce with respect to socio-economic conditions and developmental norms.

Material and methods: An anonymous retrospective questionnaire was applied and filled out by a total of 132 female students (70 from urban areas, 62 from rural areas). The questions concerned menarche age, socio-economic conditions, health, height, and weight. From the obtained data, mean values and standard deviations were calculated, and Student's $t$-test analysis was performed.

Results: Among the female students from urban areas, the majority of them, i.e. 18.57\%, achieved sexual maturity at the age of 12.0 years. Among the girls from rural areas, the majority of them (19.37\%) had their first menstruation at the age of 13.0. The mean menarche age of female students from cities is 12 years and 10 months, from the countryside -13 years and 1 month. The mean puberty age of the JKU female students is similar to the corresponding age in other regions of Poland. Conclusions: It cannot be unequivocally stated that socio-economic conditions have a crucial impact on the age of menarche. The differences between urban and rural standard of living conditions are blurring.
\end{abstract}

\section{Streszczenie}

Wprowadzenie: Wiek menarche (pierwszej miesiączki) jest początkiem końcowej fazy dojrzewania. Stosowany jest jako kryterium oceny dojrzewania płciowego dziewcząt. Mimo licznych badań zagadnienie to jest ciągle aktualne, gdyż wraz z poprawą jakości życia i warunków społeczno-ekonomicznych obserwuje się pewną tendencję do wcześniejszego dojrzewania dziewcząt.

Cel pracy: Analiza wieku menarche u studentek Wydziału Lekarskiego i Nauk o Zdrowiu Uniwersytetu Jana Kochanowskiego (UJK) w Kielcach na tle uwarunkowań społeczno-ekonomicznych oraz norm rozwojowych.

Materiał i metody: W badaniu użyto anonimowej ankiety retrospektywnej, którą zgodziły się wypełnić 132 studentki (70 pochodziło z miasta, 62 ze wsi). Pytania dotyczyły wieku pierwszej menstruacji, warunków społeczno-ekonomicznych, wiedzy na temat dojrzewania oraz wysokości i masy ciała. Z uzyskanych danych obliczano średnie i odchylenia standardowe oraz przeprowadzono analizę statystyczną testem $t$-Studenta.

Wyniki: Wśród studentek pochodzacych z miasta najwięcej (18,57\%), dojrzewało w wieku 12 lat. Spośród dziewczat pochodzących ze wsi najwięcej (19,37\%) miało pierwszą menstruację w wieku 13 lat. Średnia wieku menarche studentek z miasta to 12 lat i 10 miesięcy, a ze wsi - 13 lat i 1 miesiąc. Średni wiek dojrzewania studentek UJK jest zbliżony do wieku dziewcząt z innych regionów Polski.

Wnioski: Nie można jednoznacznie stwierdzić, że warunki społeczno-ekonomiczne istotnie wpływają na wiek pierwszej miesiączki. Zacierają się różnice pomiędzy warunkami życia w środowisku miejskim i wiejskim. 


\section{Introduction}

The age of first menstruation (menarche, i.e. the beginning of the final stage of puberty) $[1,2]$ is an important and yet the simplest criterion to assess girls' sexual maturity. For this reason, many authors undertake research in this area [3-9]. The age of the first menstruation is a result of multiple overlapping factors, both endogenous and exogenous. It is believed that girls' age of menarche is correlated with the corresponding age of their mothers [2]. On the other hand, external factors include somatotype, diet, physical activity, biogeographic environment, and socioeconomic situation [10-12].

Many authors of recent studies point to the successive lowering of the menarche age as a consequence of the secular trend [10]. This is due to the general improvement of living standards, including material conditions and social and health awareness. However, the authors of various studies have reported that early puberty timing is associated with higher risks for type 2 diabetes, obesity, and cardiovascular disease in women as a consequence of the hormonal imbalances $[4,13]$. Here we analyse the age of first menstruation in female students of the Faculty of Medicine and Health Sciences Jan Kochanowski University (JKU) Kielce and compare these findings to other regions, as well as to the whole of Poland, which provides a great deal of information about the biological development of girls. The Świętokrzyskie Province, from which the students participating in this study were recruited, is a dynamically growing region of our country.

\section{Aim of the research}

Therefore, this paper aimed to analyse the menarche age of the JKU female students depending on their socio-economic factors.

\section{Material and methods}

The study was made using an anonymous retrospective questionnaire that was completed by a total of 132 female students of the Faculty of Medicine and Health Sciences JKU, Kielce; 70 of the students were from cities, and 62 were from the countryside. In the survey, the urban origin was divided into two subcategories: cities with up to 50,000 residents (27 girls) and cities with greater than 50,000 residents (43 students). The research tool was the author's questionnaire; the questions concerned menarche age, education of parents, number of siblings, socio-economic conditions, health, body height, and body weight. The student's responses were categorised. The students were not weighed and measured, and that the given results are declarative, and body mass index (BMI) index was calculated based on those values. Relevant consent was obtained to perform the study from the Bioethical
Commission of the Faculty of Medicine and Health Sciences JKU in Kielce (No. 14/2017). The obtained data were processed statistically.

\section{Statistical analysis}

Mean values were calculated $(\bar{x})$ along with standard deviations (s) and significance of differences between the average Student's $t$-test, using Statistica 12 software. The assumed level of significance was $p \leq 0.05$. The study results were compared with the results reported by other authors.

\section{Results}

\section{Menarche age}

The age range of menarche in the studied students was broad: from 10 years 5 months (one person from a rural area) to 16 years 1 month (1 person from a village). In general, the majority of girls from urban areas commenced puberty at $12(18.57 \%)$ and $13(11.43 \%)$ years old. In the case of girls from the countryside, the most matured were 13.0 and 12.0 years old $(19.37 \%$ and $12.9 \%$, respectively). Detailed data on this can be found in Table 1 and Figure 1. The mean age at first menstruation in girls from rural areas was 13.23 years (i.e. 13 years and 3 months, $s=1.165$ ).

In the case of girls from urban areas, $\bar{x}=12.81$ (12 years 10 months) and $s=1.149$. An analysis of the mean values of the age at first menstruation for the two social groups using Student's $t$-test showed the differences to be not statistically significant.

In some studies, the results obtained were compared across three categories of puberty: early (up to 11 years of age), average (11-14 years of age), and late (over 14 years of age). The timing of the first menstruation in the vast majority of the surveyed girls was "average" (75.81\% of girls from rural areas and 77.14\% of girls from urban areas). In small towns the average age of puberty reached $42.1 \%$ of female students, while in large cities as much as $90.19 \%$ (Table 2).

\section{Living conditions}

The socio-economic conditions of the students, the place of residence, parents' education, number of siblings, diet, sources of knowledge about puberty, and BMI were taken into consideration.

The majority of the surveyed girls $(96.8 \%$ and 91.4\% from villages and cities, respectively) grew up in a full family with both parents.

Considering the education of parents, it should be noted that about one-third of the parents completed higher education, one-third secondary education, and one-third vocational education. There were no statistically significant differences in parents' education when comparing the studied social groups with regard to higher and secondary education but differences were found concerning vocational education 
Table 1 . Puberty age of female students from urban and rural areas

\begin{tabular}{|c|c|c|c|c|}
\hline \multirow{2}{*}{$\begin{array}{l}\text { Puberty age } \\
\text { [years } \\
\text { and months] }\end{array}$} & \multicolumn{2}{|c|}{ Village } & \multicolumn{2}{|r|}{ City } \\
\hline & $N$ & $\%$ & $N$ & $\%$ \\
\hline 10.5 & 1 & 1.61 & & \\
\hline 11.0 & 1 & 1.61 & 3 & 4.29 \\
\hline 11.4 & & & 1 & 1.43 \\
\hline 11.5 & & & 1 & 1.43 \\
\hline 11.6 & 2 & 3.23 & 3 & 4.28 \\
\hline 11.7 & 1 & 1.61 & 2 & 2.86 \\
\hline 11.8 & 1 & 1.61 & & \\
\hline 11.10 & & & 3 & 4.28 \\
\hline 11.11 & & & 1 & 1.43 \\
\hline 12.0 & 8 & 12.9 & 13 & 18.57 \\
\hline 12.1 & 2 & 3.23 & 1 & 1.43 \\
\hline 12.2 & 2 & 3.23 & 1 & 1.43 \\
\hline 12.3 & & & 1 & 1.43 \\
\hline 12.4 & & & 1 & 1.43 \\
\hline 12.5 & 2 & 3.23 & 3 & 4.28 \\
\hline 12.6 & 2 & 3.23 & 2 & 2.86 \\
\hline 12.7 & 1 & 1.61 & & \\
\hline 12.9 & & & 1 & 1.43 \\
\hline 12.10 & 1 & 1.61 & & \\
\hline 13.0 & 12 & 19.36 & 8 & 11.43 \\
\hline 13.1 & & & 3 & 4.28 \\
\hline 13.2 & 2 & 3.23 & 2 & 2.86 \\
\hline 13.3 & 2 & 3.23 & & \\
\hline 13.4 & 1 & 1.61 & 1 & 1.43 \\
\hline 13.5 & 2 & 3.23 & & \\
\hline 13.6 & 1 & 1.61 & 1 & 1.43 \\
\hline 13.7 & 1 & 1.61 & 1 & 1.43 \\
\hline 13.9 & 2 & 3.23 & & \\
\hline 13.10 & 1 & 1.61 & & \\
\hline 13.11 & & & 1 & 1.43 \\
\hline 14.0 & 5 & 8.06 & 4 & 5.71 \\
\hline 14.1 & & & 1 & 1.43 \\
\hline 14.2 & & & 3 & 4.28 \\
\hline 14.3 & 2 & 3.23 & 1 & 1.43 \\
\hline 14.4 & 1 & 1.61 & 1 & 1.43 \\
\hline 14.6 & 1 & 1.61 & & \\
\hline 14.9 & & & 1 & 1.43 \\
\hline 14.10 & & & 1 & 1.43 \\
\hline 15.0 & & & 2 & 2.86 \\
\hline 15.1 & 1 & 1.61 & & \\
\hline 15.2 & 1 & 1.61 & & \\
\hline 15.4 & & & 1 & 1.43 \\
\hline 16.0 & 2 & 3.23 & 1 & 1.43 \\
\hline 16.1 & 1 & 1.61 & & \\
\hline$\sum$ & 62 & 100 & 70 & 100 \\
\hline $13.07258=13.1$ & & $\begin{array}{l}\text { Average } \\
\text { value }(\bar{x} \bar{x})\end{array}$ & & $\begin{array}{c}12.81057= \\
12.10\end{array}$ \\
\hline 1.164884 & & s & & 1.148905 \\
\hline 1.356954 & & Variance & & 1.319982 \\
\hline
\end{tabular}

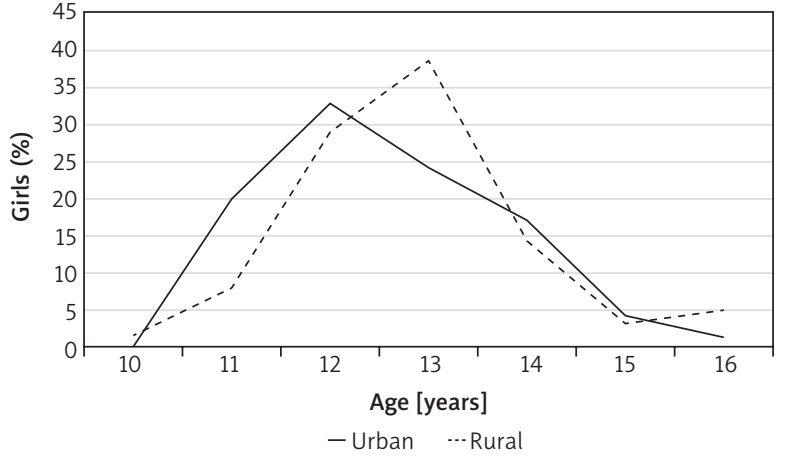

Figure 1. Puberty age of female students of JKU from urban (solid line) and rural areas (dotted line)

( $p=0.005)$. Also, no differences were found concerning the number of siblings. However, we did detect some differences concerning the student's declarations regarding living conditions. Most (68.6\%) of the students from urban areas indicated very good living conditions, while this proportion was only $9.7 \%$ among students from rural areas. Most of the girls from rural areas $(79.0 \%)$ indicated good living conditions.

A vast majority of female students were eating regularly before the onset of their first menstrual period; while only $9.8 \%$ were eating irregularly (more in the case of female students from urban areas). Nearly all of the surveyed girls were not dieting, while only $3.8 \%$ were on a short-term diet that lasted between one and several months $(84.3 \%$ of female students from urban and $96.8 \%$ from rural areas).

The girls' eating habits were different: the diet of $33.3 \%$ was dominated by carbohydrates and fruit and vegetables. Only one-fifth of the surveyed students indicated meat (including fish) as the main element of their diet, while $11.4 \%$ indicated dairy products. Significant differences between the nutrition of students from rural and urban areas were not disturbed (Table 3). Most (92.4\%) of the surveyed students claimed they were eating the same way at menarche age.

Regarding the students' proportions of body structure at the age of the first menstrual period, $45 \%$ declared the same proportions, 54\% were slightly slimmer, and 33\% were more obese. When analysing the mean values of the BMI ratio of girls from urban and rural areas, it should be noted that they were very similar (21.33 and $21.77 \mathrm{~kg} / \mathrm{m}^{2}$, respectively). The majority $(88.7 \%)$ of girls from rural areas had a correct body build (BMI in the range of $18.5-24.99 \mathrm{~kg} / \mathrm{m}^{2}$ ). Only $4.84 \%$ were underweight (BMI $<18.5 \mathrm{~kg} / \mathrm{m}^{2}$ ): two girls from the group of 13-year-olds and one from the group of 12 -year-olds. Similarly, only $6.45 \%$ were overweight: three people from the group of 12-yearolds and one from the group of 13-year-olds. Among the girls from urban areas, the situation was similar: $82.9 \%$ were of proper body build, and $5.7 \%$ were un- 
Table 2. The menarche age of the UJK female students with division into early, average, and late puberty

\begin{tabular}{|c|c|c|c|c|c|c|c|}
\hline \multirow[t]{2}{*}{ Social origin } & & \multicolumn{2}{|c|}{ Early puberty } & \multicolumn{2}{|c|}{ Average puberty } & \multicolumn{2}{|c|}{ Late puberty } \\
\hline & & $N$ & $\%$ in group & $N$ & $\%$ in group & $N$ & $\%$ in group \\
\hline Village $(n=62)$ & & 1 & 1.61 & 47 & 75.81 & 14 & 22.58 \\
\hline City $(n=70)$ & & 0 & 0 & 54 & 77.14 & 16 & 22.86 \\
\hline \multirow[t]{2}{*}{$\begin{array}{l}\text { City with division into small } \\
\text { and big }\end{array}$} & $\begin{array}{c}<50,000 \text { inhabitants } \\
(n=19)\end{array}$ & 0 & 0 & 8 & 42.1 & 11 & 57.9 \\
\hline & $\begin{array}{c}>50,000 \text { inhabitants } \\
(n=51)\end{array}$ & 0 & 0 & 46 & 90.19 & 5 & 9.81 \\
\hline
\end{tabular}

derweight (two 11-year-olds and two 12-year-olds). Overweight girls accounted for 11.4\% (two 11-yearolds and three in each group of 12- and 13-year-olds Table 3.

Only a few of the surveyed female students were chronically ill (1.5\%). As far as people from the students' families are concerned, in more than half of the cases (53\%) no diseases were found. In $18.2 \%$ of cases, the parents were sick, in $15.9 \%$ the siblings were sick, and in $12.9 \%$ members of the extended family were sick.

\section{Discussion}

Currently, girls are starting puberty at an even younger age, which is measurable by the appearance of the first menstrual period. It is believed that this is the result of coexisting genetic factors and a broadly understood socio-economic environment. According to Olszewska et al. [4] and Olesen et al. [11], in the $20^{\text {th }}$ century, the mean age of menarche in Europe was 15 . It is currently $12-13$ years $[13,14]$. Therefore, the reduction in the age of the first menstrual period is accelerating. This is explained by, among others, improvement of living conditions, change in eating habits, and increased health awareness.

The mean menarche age of girls from various geographical regions of Poland ranges from 12 to 13 years (Table 4 ) - from 12 years 5 months to 12 years 11 months in the case of girls from urban areas and from 12 years 5 months to 13 years 4 months in girls from rural areas. The mean age of puberty among students of JKU in Kielce from urban areas is not dissimilar from the Polish data. In the case of the girls from rural areas, the mean age of 13 years and 1 month is similar to the mean age of girls from the Pomorze region (13 years and 4 months) and Rzeszow and Zielona Gora regions (12 years and 11 months), while it is slightly higher than the mean age of the girls from Bydgoszcz (by 7 months). The differences among these values are not large and fall within a statistical error limit. Considering the age range of the first menstrual period of the surveyed students (10 years 5 months 16 years 1 month), it is similar to other authors from Poland (9 years 5 months - 16 years 6 months) $[1-5,8$, 13-15]. Considering the division of menarche age into early puberty (up to 11 years), average (11-14 years), and late (over 14 years), the majority of surveyed girls became mature at an "average age".

When analysing the list above, one can draw the following conclusions. The mean puberty age of female students at JKU in Kielce was attained by $75.81 \%$ of girls from rural areas and $77.14 \%$ girls from urban areas. When comparing girls from large cities (over 50,000 residents) and towns (less than 50,000 residents), the values are quite different: as many as $90.19 \%$ of girls from cities reached puberty within the average age range, while in the case of girls from urban areas more than half (57.9\%) reached puberty late (over 14 years of age) and $42.1 \%$ reached puberty at the average age. However, it seems that for students from urban areas, from which only 19 female students originated, the results need to be treated carefully. Of the surveyed female students, only one person reached puberty early; interestingly, this girl came from a rural area. A surprising proportion of the girls became mature late $22.58 \%$ of girls from rural areas and $22.85 \%$ of girls from urban areas). In the case of girls from urban areas, this value was only $9.81 \%$. When comparing these results with the data of other authors $[4,5]$, attention should be paid to the similar percentage distributions in particular age categories, especially with respect to the girls from the Podkarpackie region. The situation is different for the students from the Pomeranian Medical University in Szczecin, in which there was a relatively large group of girls who went through puberty earlier (14.01\%).

When one compares the obtained results with the results of studies among girls from primary and secondary schools in Kielce [2], it should be stated that the mean puberty age of students from cities is similar to the results of the studies by Zięba et al. (i.e. 12 years and 10 months), while in the case of female students from rural areas, the mean age is 11 months older among primary and secondary school students (Table 4).

According to the literature data, girls who commence puberty earlier have a higher BMI or a tendency for obesity $[2,8,14,16]$. In this research, this dependence was impossible to confirm because only one female student reached sexual maturity earlier 
Table 3. Socio-economic conditions of the female students at JKU in Kielce

\begin{tabular}{|c|c|c|c|c|c|c|c|c|c|}
\hline \multicolumn{2}{|c|}{ Type of socio-economic conditions } & \multicolumn{2}{|c|}{ Village } & \multicolumn{2}{|c|}{ City } & \multicolumn{2}{|c|}{ Total } & \multicolumn{2}{|c|}{ Statistical significance } \\
\hline & & $n / 62$ & $\%$ & $n / 70$ & $\%$ & $n / 132$ & $\%$ & $\chi^{2}$ & $P$-value \\
\hline \multirow[t]{3}{*}{ Upbringing } & Full family & 60 & 96.8 & 64 & 91.4 & 124 & 93.9 & & \\
\hline & Only mother & 2 & 3.2 & 5 & 7.1 & 7 & 5.3 & & \\
\hline & Only father & & & 1 & 1.4 & 1 & 0.76 & & \\
\hline \multirow[t]{8}{*}{ Education } & Higher mothers & 26 & 41.9 & 21 & 30.0 & 47 & 35.6 & \multirow{2}{*}{2.0309} & \multirow{2}{*}{0.154131} \\
\hline & Higher fathers & 16 & 25.8 & 24 & 34.9 & 40 & 30.3 & & \\
\hline & Secondary mothers & 21 & 33.9 & 22 & 31.5 & 43 & 32.6 & \multirow{2}{*}{1.72} & \multirow{2}{*}{0.185693} \\
\hline & Secondary fathers & 15 & 24.2 & 28 & 40.0 & 43 & 32.6 & & \\
\hline & Vocational mothers & 13 & 21.0 & 26 & 37.1 & 39 & 29.5 & \multirow{4}{*}{7.929} & \multirow{4}{*}{0.004865} \\
\hline & Vocational fathers & 30 & 48.4 & 17 & 24.3 & 47 & 35.6 & & \\
\hline & Primary mothers & 2 & 3.2 & 1 & 1.4 & 3 & 2.3 & & \\
\hline & Primary fathers & 1 & 1.6 & 1 & 1.4 & 2 & 1.5 & & \\
\hline \multirow[t]{5}{*}{ Siblings } & 1 & 26 & 41.9 & 36 & 51.4 & 62 & 47 & \multirow{5}{*}{1.6342} & \multirow{5}{*}{0.802626} \\
\hline & 2 & 22 & 35.5 & 21 & 30.0 & 43 & 32.6 & & \\
\hline & 3 & 6 & 9.7 & 7 & 10.0 & 17 & 9.8 & & \\
\hline & More & 6 & 9.7 & 4 & 5.7 & 10 & 7.6 & & \\
\hline & Only child & 2 & 3.3 & 2 & 2.9 & 4 & 3.0 & & \\
\hline \multirow{3}{*}{$\begin{array}{l}\text { Living } \\
\text { conditions }\end{array}$} & Very good & 6 & 9.7 & 48 & 68.6 & 54 & 40.9 & \multirow{3}{*}{47.5178} & \multirow{3}{*}{$8 \quad 0.00001$} \\
\hline & Good & 49 & 79.0 & 18 & 25.7 & 67 & 50.8 & & \\
\hline & Satisfactory & 7 & 11.3 & 4 & 5.7 & 11 & 8.3 & & \\
\hline \multirow{7}{*}{$\begin{array}{l}\text { Information } \\
\text { about the } \\
\text { first } \\
\text { menstrual } \\
\text { period }\end{array}$} & Conversation with parents & 33 & 53.2 & 54 & 77.1 & 87 & 65.9 & & \\
\hline & Biology lessons & 18 & 29.0 & 29 & 41.4 & 47 & 35.6 & & \\
\hline & Female friends & 14 & 22.6 & 14 & 70 & 28 & 13.6 & & \\
\hline & Books & 10 & 16.1 & 10 & 14.3 & 20 & 15.2 & & \\
\hline & The Internet & 10 & 16.1 & 9 & 12.9 & 19 & 14.4 & & \\
\hline & Older sisters & 2 & 3.2 & 8 & 11.4 & 10 & 7.6 & & \\
\hline & Other sources & 6 & 9.7 & 7 & 10.0 & 13 & 9.8 & & \\
\hline \multirow{2}{*}{$\begin{array}{l}\text { Eating } \\
\text { habits }\end{array}$} & Regular & 60 & 96.8 & 59 & 84.3 & 119 & 90.2 & \multirow{2}{*}{5.7755} & \multirow{2}{*}{0.016257} \\
\hline & Irregular & 2 & 3.2 & 11 & 15.7 & 13 & 9.8 & & \\
\hline \multirow{4}{*}{$\begin{array}{l}\text { Type } \\
\text { of diet }\end{array}$} & Carbohydrates & 20 & 32.3 & 24 & 34.3 & 44 & 33.3 & \multirow{4}{*}{0.8355} & \\
\hline & Vegetables and fruits & 23 & 37.1 & 21 & 30.0 & 44 & 33.3 & & 0810956 \\
\hline & Meat (including fish) & 12 & 19.4 & 15 & 21.4 & 27 & 20.5 & & ט \\
\hline & Dairy products & 7 & 11.3 & 10 & 14.3 & 17 & 11.4 & & \\
\hline $\begin{array}{l}\text { Chronic } \\
\text { diseases }\end{array}$ & Yes & 2 & 3.2 & & & 2 & 1.5 & & \\
\hline BMI & Normal & 55 & 88.7 & 58 & 82.9 & 113 & 85.6 & & \\
\hline & Underweight & 3 & 4.8 & 4 & 5.7 & 7 & 5.3 & 10710 & 658126 \\
\hline & Overweight & 4 & 6.45 & 8 & 11.4 & 12 & 9.1 & 1.0149 & $0.504<20$ \\
\hline & Average & & & & & 21. & & & \\
\hline
\end{tabular}


Table 4. The age of first menstruation of girls from various regions of Poland (as per various authors)

\begin{tabular}{|c|c|c|c|c|c|c|c|c|}
\hline Region & $\begin{array}{l}\text { Kielce } \\
\text { UJK }\end{array}$ & $\begin{array}{l}\text { Kielce } \\
\text { Zięba } \\
\text { et al., } \\
2012\end{array}$ & $\begin{array}{l}\text { Bydgoszcz } \\
\text { Nowicki, } \\
1996\end{array}$ & $\begin{array}{c}\text { Pomorze } \\
\text { Zaworski, } \\
2008\end{array}$ & $\begin{array}{l}\text { Kraków } \\
\text { Kowal, } \\
\text { Cichocka, } \\
2011\end{array}$ & $\begin{array}{c}\text { Rzeszów } \\
\text { Radochońska } \\
\text { et al. 2006, } \\
\text { Nowak, 2005* }\end{array}$ & $\begin{array}{c}\text { Zielona Góra } \\
\text { Asienkiewicz, } \\
\text { Wandycz } \\
2017\end{array}$ & $\begin{array}{c}\text { Końskie } \\
\text { Umławska, } \\
\text { Krzyżanowska } \\
2008\end{array}$ \\
\hline Urban & 12 y $10 \mathrm{~m}$ & 12 y $3 \mathrm{~m}$ & 12 y $8 \mathrm{~m}$ & 12 y $11 \mathrm{~m}$ & 12 y $5 \mathrm{~m}$ & 12 y $7 \mathrm{~m}$ & 12 y 7 m & 12 y $5 \mathrm{~m}$ \\
\hline Rural & 13 y 1 m & 12 y $2 \mathrm{~m}$ & 12 y $4 \mathrm{~m}$ & 13 y 4 m & & $\begin{array}{l}12 \text { y } 6 \mathrm{~m} \\
12 \text { y } 11 \mathrm{~m}\end{array}$ & 12 y $9 \mathrm{~m}$ & 12 y $5 \mathrm{~m}$ \\
\hline
\end{tabular}

(10 years 5 months). In her case, the BMI was $22.32 \mathrm{~kg} / \mathrm{m}^{2}$, which means that the body build was correct. According to Kaplowitz et al. [16] and Umławska and Kolasa [6], early puberty is not always related to obesity. According to the secular trend, girls are undergoing puberty earlier, but they also take on a slender figure. In the opinion of these authors, contrary to the general opinion, there is no simple causeeffect relationship between early puberty and obesity. In the mind of Wasiluk and Szczuk [17], excessive weight is more frequently observed in urban youths, and according to the data of some authors, urban girls achieve puberty earlier than their rural peers.

In girls who enter puberty at a late stage, the BMI is relatively low (e.g. $19 \mathrm{~kg} / \mathrm{m}^{2}$ ) [7]. Among the surveyed JKU female students there were 30 students in this group (14 from rural areas and 16 from urban areas). In the majority of these students, the BMI values ranged from 20.0 to $24.6 \mathrm{~kg} / \mathrm{m}^{2}$, and the value was lower than $19 \mathrm{~kg} / \mathrm{m}^{2}$ in only three cases. This is compliant with the results of the studies carried out by Krawczyńska and Łukawska [18], who indicated that the majority of youths had an average body mass.

Olszewska et al. [4], when analysing socio-economic factors such as place of residence, the number of siblings, or parents' education, stated that none of them significantly affected the pace of puberty. Similarly, our results did not display such dependencies.

When discussing the issue of girls' puberty, one should consider all of the genetic and socio-economic conditions, including eating habits, parents' education, self-esteem, and motivation of a healthy lifestyle among girls, as indicated by multiple studies (e.g. Nowak-Starz and Zięba [19], Zając et al. [20], and Szczekala et al. [21]). It should also be noted that the current standard of living in rural areas is not very different from the urban standard, and in some cases is even better. This is due to education, increased pro-health awareness, and improved living conditions. Half of the students $(50.8 \%)$ stated that their conditions were good, $40.9 \%$ very good, and $8.3 \%$ satisfactory. The majority of the surveyed students were eating regularly and were not on any diets. Their diet was dominated by carbohydrates, fruit, and vegetables, while meat was less represented. All of the surveyed students knew about puberty before their first menstrual pe- riod. In terms of sources of such knowledge, $65.9 \%$ indicated conversations with their parents. This is undoubtedly related to the level of parents' education, their increased awareness, and trust among youths towards their relatives. The other sources indicated by students included biology classes, older female friends, books, and the Internet. It seems that the role of the Internet in obtaining information about the structure and functioning of bodies among youths is significant (14.4\% of girls listed this source in our survey) [22].

\section{Conclusions}

Despite the significant span of menarche age (10 years 5 months - 16 years 1 month), the majority of female students reached puberty at the age of 12. Some influence of social and economic factors on the age of menarche was observed; the girls from urban areas become mature, on average, 5 months earlier than their peers from rural areas. The mean age of puberty among female students at JKU in Kielce is not very different from the average in other regions. The female students from the surveyed social environments possessed knowledge about puberty before their menarche age. The eating habits, BMI values, and the standard of living of girls from rural and urban areas were not significantly different.

\section{Conflict of interest}

The authors declare no conflict of interest.

\section{References}

1. Nowak M. Wiek menarche dziewcząt wiejskich z województwa podkarpackiego w latach 2004-05. Now Lek 2011; 80: 429-440.

2. Zięba E, Nowak-Starz G, Karakiewicz B, Markowska M, Krawczyńska J, Skawiński D. Rozwój somatyczny dziewcząt z zaburzeniami miesiączkowania i bez zaburzeń w stanie zdrowia i rozwoju w aspekcie wybranych wskaźników wagowo-wzrostowych. Medical Studies 2012; 25: 51-59.

3. Międzypokoleniowe zmiany w budowie ciała i akceleracja pokwitania u młodzieży $\mathrm{w}$ wieku $7-15$ lat z populacji wielkomiejskiej $\mathrm{w}$ świetle uwarunkowań psychosocjalnych. Kowal M, Cichocka B (eds.). Monografia Nr 5 AWF Kraków 2011.

4. Olszewska K, Kliś K, Teul I, Wronka I. Wczesny wiek menarche - związek ze statusem społeczno-ekonomicz- 
nym oraz wybranymi czynnikami związanymi ze stanem zdrowia. Pom J Life Sci 2015; 61: 94-98.

5. Radochońska A, Dudzik S, Perenc L. Zmiany sekularne wieku menarche u dziewcząt z Boguchwały i Krasnego badanych w latach 1976/77, 1988/89 oraz 2003/04 na tle populacji dziewcząt rzeszowskich. Przeg Med Uniw Rzeszowskiego 2006; 1: 64-69.

6. Umławska W, Kolasa E. Zmiany w budowie ciała i dojrzewaniu płciowym maturzystek wrocławskich w latach 1976-1999. Ped Pol 2005; 80: 763-769.

7. Umławska W, Krzyżanowska M. Ocena poziomu rozwoju fizycznego dziewcząt $w$ okresie pokwitania na przykładzie uczennic z Końskich. Wiad Lek 2008; 41: 37-42.

8. Wronka I. Wpływ czynników społeczno-ekonomicznych na wiek menarche. In: Księga jubileuszowa. Kaczanowski K (ed.). Wyd. Plus, Kraków 2008; 281-297.

9. Zaworski B. Wiek menarche dziewcząt $z$ terenu województwa pomorskiego w XX i na początku XXI wieku. Słupskie Prace Biol 2008; 5: 13-150.

10. Parent AS, Teilmann G, Juul A, Skakkebaek NE, Toppari J, Bourguignon JP. The timing of normal puberty and the age limits of sexual precocity: variations around the world, secular trends, and changes after migration. Endocr Rev 2003; 24: 668-693.

11. Olesen AW, Jeune B, Boldsen JL. A continuous decline in menarcheal age in Denmark. Ann Hum Biol 2000; 27: 337-348.

12. Asienkiewicz R, Wandycz A. Wiek menarche a poziom rozwoju morfofunkcjonalnego studentek Uniwersytetu Zielonogórskiego. In: Profilaktyka i Edukacja Zdrowotna. NeuroCentrum, Lublin 2017; 11-27.

13. Day F, Elks CE, Murray A, Ong KK, Perry JR. Puberty timing associated with diabetes cardiovascular disease and also diverse health outcomes in man and women: the UK Biobank study. Sci Rep 2015; 5: 11208.

14. Ribeiro J, Santos P, Duarte J, Mota J. Association between overweight and early sexual maturation in Portuguese boys and girls. Ann Hum Biol 2006; 33: 55-63.

15. McIntyre $\mathrm{MH}$. Adult stature, body proportions and age at menarche in the United States National Health and Nutrition Survey (NHANES) III. Ann Hum Biol 2011; 38: 716-720.

16. Kaplowitz PB, Slora EJ, Wasserman RC, Pedlow SE, Herman-Giddens ME. Earlier onset of puberty in girls: relation to increased body mass index and race. Pediatrics 2001; 108: 347-353.

17. Wasiluk A, Szczuk J. Unredweight, overweight, and obesity in boys and girls at age of 7-18 years from eastern Poland in the years 1986-2006. Medical Studies 2015; 31: 99-105.

18. Krawczyńska J, Łukawska P. Health-related quality of life of adolescent in the context of selected somatic development indices. Medical Studies 2016; 32: 189-195.

19. Nowak-Starz G, Zięba E. Lifstyle related to health and quality of life of girls at puberty in light of the KIDSCREEN-52 Questionnaire. Medical Studies 2017; 33: 117-126.

20. Zając P, Grochowska A, Suliga E. The association between calcium consumption and students body composition. Medical Studies 2017; 33: 184-190.

21. Szczekala KM, Ślusarska BJ, Goś AB. Motivationaly interviewing i obesity reduction. Medical Studies 2017; 33: 73-80.
22. Nowicki G. Środowisko społeczno-wychowawcze jako czynnik różnicujący wiek menarche u dziewcząt regionu bydgoskiego. Przeg Antropol 1996; 59: 107-114.

\section{Address for correspondence:}

\section{Prof. Tadeusz Kuder}

Department of Anatomy

Institute of Medical Sciences

Faculty of Medicine and Health Sciences

Jan Kochanowski University

al. IX Wieków Kielc 19 A, 25-317 Kielce, Poland

Phone: +48697142667

E-mail: tkuder@ujk.edu.pl 